\title{
The changing landscape of surgery for Crohns disease
}

Anna Levin, Anton Risto and Pär Myrelid

The self-archived postprint version of this journal article is available at Linköping University Institutional Repository (DiVA):

http://urn.kb.se/resolve?urn=urn:nbn:se:liu:diva-173983

N.B.: When citing this work, cite the original publication.

Levin, A., Risto, A., Myrelid, P., (2020), The changing landscape of surgery for Crohns disease, SEMINARS IN COLON AND RECTAL SURGERY, 31(2), 100740.

https://doi.org/10.1016/j.scrs.2020.100740

Original publication available at:

https://doi.org/10.1016/j.scrs.2020.100740

Copyright: Elsevier

http://www.elsevier.com/

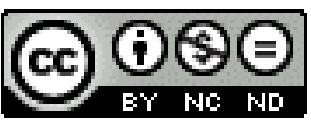




\title{
The changing landscape of surgery for Crohn's disease
}

Anna Levin MD, Anton Risto MD, Pär Myrelid MD, PhD, Associate Professor

Department of Surgery, Linköping University Hospital and Department of Clinical and Experimental Medicine, Linköping University, Linköping, Sweden

Correspondence and reprint requests: Pär Myrelid, Department of Surgery, University hospital Linköping, SE-581 85 Linköping, Sweden, +46-0101031581 par.myrelid@liu.se

Key Words: Crohn's disease, Biological therapy, Immunomodulators, Surgery

\begin{abstract}
Abbreviations: Crohn's Disease (CD), Inflammatory Bowel Disease (IBD), Anti-Tumor Necrosis Factor (aTNF), Immunomodulators (IM), Azathioprine (AZA), Mercaptopurine (MP), Methotrexate (MTX), Ileal Pouch Anal Anastomosis (IPAA), Continent lleostomy (CI), Multidisciplinary team conference (MDT)
\end{abstract}

Conflict of Interest: None declared 


\section{Abstract}

The incidence of Crohn's disease is increasing world-wide and the disease location and behavior is changing towards more colonic as well as inflammatory behavior. As previous data have spoken towards ileal disease and stricturing and penetrating disease to be the indications most in need of surgery, one could expect the surgical load to decrease. As these changes are relative, the absolute numbers of surgical interventions are less affected. There are also data showing an increasing complexity among patients at time of surgery. Finally, a new role for surgery as initial therapy to induce remission instead of biologic therapy in ileal or ileocaecal disease has been suggested. In order to improve the care for patients with Crohn's disease in general, and the peri-operative phase in particular, the use of multidisciplinary team discussions is essential. In conclusion, the role of surgery is changing. Fewer patients need surgery, but when they do they have more complex disease. In the future, ileocaecal resection may be used increasingly as initial therapy to induce remission in a true top-down approach. 


\section{Introduction}

Crohn's disease (CD) is an inflammatory bowel disease (IBD) characterized by discontinuous (often referred to as skip lesions) transmural inflammation involving any portion of the gastrointestinal tract ${ }^{12}$. The original description by Crohn et al was of a regional ileitis ${ }^{3}$ and the classical ileocecal type of the disease was affecting the ileum and cecum. There is quite often a time lag between the first symptoms and the eventual CD diagnosis ${ }^{4}$. Symptoms are dominated by crampy abdominal pain, bowel obstructions and diarrhoea. However, fistulas, intestinal as well as perianal, are quite frequent and after 20 years disease duration up to $50 \%$ of patients may have suffered of at least one episode of fistulation ${ }^{5-7}$. The disease sometimes causes growth retardation and/or delayed puberty in children and adolescents and weight-loss and malnutrition in adults, both due to less food intake but also due to the inflammatory activity and sometimes by-passes created by fistulas ${ }^{689}$.

There is as yet no gold standard diagnosing $C D^{10}$, hence it remains a test of clinical skill depending on relevant patient history, thorough physical examination, laboratory testing, and detailed review of radiographic, endoscopic, and pathologic reports ${ }^{10}$. The disease is nowadays classified according to the Montreal classification (Table 1) aiming to describe the different forms of severity in $\mathrm{CD}^{11}$. In general terms, younger age at diagnosis, wider spread in the intestinal tract and more complicated disease predicts worse long-term outcome.

As $C D$ is a chronic disease with no definite cure, it may have a severe impact on quality of life compared with the general population due to lack of energy, pain, diarrhea, malnutrition, perianal disease, ostomy-related concerns and the uncertain nature of disease in general ${ }^{12-}$ 14. Previous studies have shown that such impairment in quality of life is more associated 
with severe disease activity rather than the disease itself or even the localization or behavior of the disease ${ }^{1315-20}$. The different therapies for $C D$ are focused on relief of symptoms and dealing with complications to the disease. In active disease, induction of remission can be achieved either through medical therapy or surgery. When patients have no or limited symptoms therapies are aimed at maintenance of remission and to prevent relapsing of symptoms and need of further surgery. It is important to remember that most patients spend most of their life in remission ${ }^{21}$ and that medical therapy and surgery are used as complementary therapies can achieve remission with low symptomatic load in many patients ${ }^{22} 23$. The correlation between remission and quality of life is strong, regardless if remission was achieved medically or surgically 2425 .

The disease has for a long time had a very high incidence and prevalence in western and northern countries with Sweden, Canada and northern US having among the highest incidences, but is today getting more common also in previously low incident regions ${ }^{26}$. The location of $\mathrm{CD}$ within the gastrointestinal tract seems to have changed somewhat over time. Originally described as a segmental ileitis (L1, Table 1 ) this location has, in relative measures, decreased in favour of CD colitis (L2) and ileocolitis (L3) $)^{27} 28$. Apart from the change in the location of the disease there are also a number of reports on a shift towards more patients diagnosed either very early $(A 1)$ or late in life $(A 3)^{2729}$ as well as less frequent occurrence of stricturing (B2) or penetrating disease $(\mathrm{B} 3)^{27}$.

\section{Primary medical therapy}

Originally steroids were the only drug used in CD. Later on slow-release formulas and development of budesonide, with a high first passage metabolism in the liver, has improved 
the effect and with somewhat less side-effects. Long term use of steroids do however have severe side effects and in modern CD therapy the basis of medical therapy has shifted to immunomodulators (e.g. azathioprine (AZA) and mercaptopurine (MP)), methotrexate (MTX)) and so-called biological therapies. The first type of biological therapy was the antibodies targeted at the tumor necrosis factor receptor (aTNF), e.g. infliximab (IFX), adalimumab and golimumab. These have since been followed by other antibodies targeting other receptors involved in the inflammatory cascade, i.e. vedolizumab and ustekinumab ${ }^{30}$. Vedolizumab is an antibody targeted against the $\alpha 4 \beta 7$ receptors of circulating lymphocytes that normally migrate into the gastrointestinal tract, and thus preventing them from reaching their goal, while the antibody ustekinumab diminishes the intestinal inflammation by targeting receptors for interleukins 12 and 23.

The medical treatment has also in some ways gone from a gradual step-up of medication ${ }^{31}$ to a more rapid step-up, or even a "top-down-approach" in selected patients ${ }^{32}{ }^{33}$. Whether this change in strategy really has modified the course of the disease or the need of surgery is still debated $^{3435}$ and at the same time there has been a vast change in the costs for the healthcare of IBD patients. Up to the turn of the millennium, hospitalization and surgery were the major cost drivers in IBD care, but a recent Dutch study found aTNF use to be the main costs driver currently, accounting for $64 \%$ of the total cost in CD, while surgery accounted for less than $1 \%$ of the healthcare costs in $C D^{36}$.

\section{Surgical therapy}

The disease was first treated with extensive resection ${ }^{37}$, with the inherent risk of developing short bowel syndrome and intestinal failure ${ }^{38}{ }^{39}$. The extent of surgical resection has since repeatedly been shown to be of less importance for treatment outcome ${ }^{40-42}$, and today 
bowel-preserving techniques are preferred, such that inflamed areas are not always surgically removed (unless engaged in fibrotic strictures and/or fistulas) and short strictures may be treated by strictureplasty instead of resection ${ }^{43-46}$.

Surgical therapy should be applied according to both location and behavior of the disease but also to where in their life span the patients is as well as the effect on the patient, e.g. delayed growth or puberty in children and adolescents. In general, indications for surgery in $\mathrm{CD}$ has been the treatment of complications of the disease, e.g. stricturing and/or penetrating disease (Table 1). Prior to the end of the last millennium, and before the wider spread of immunomodulating and biological therapy, about $50 \%$ of patients underwent abdominal surgery within 10 years of their $C D$ diagnosis ${ }^{47}{ }^{48}$. Decreasing surgical rates have been reported during the last 50 years down to $24-27 \%$ after 5 years from diagnosis after $1990^{49}$. The studies included in the meta-analysis by Frolkis et al are however heterogeneous and a vast majority of the included patients were diagnosed prior to the introduction of IM and aTNF, with scarce or no information on type of surgical procedures. In a more recent study from Sweden the cumulative incidence for first abdominal surgery within ten years of CD diagnosis were as low as 21\% for patients diagnosed between 2004 and 2009 and the cumulative incidence of a repeated abdominal procedure five years following the primary procedure was only $15 \%$ among those patients diagnosed with CD in $1996-2000^{50}$. A similar finding was presented by Jeuring et al from the Netherlands who found decreasing trends in need of hospitalization as well as use of surgery in CD while no change was seen in disease progression ${ }^{51}$. The use of IM and aTNF increased significantly over time but in a matched control using propensity-score no differences in hospitalization, surgery, or phenotype progression were found between patients with or without IM or aTNF therapy. In another 
study the occurrence of bowel resections were compared in patients with long-term ( $>12$ months) and short-term use ( $<12$ months) of aTNF and no difference was found between the two groups ${ }^{35}$.

lleocecal resection is today still the most common procedure in $\mathrm{CD}$ and in a recent study from the US no decrease could be seen in the period 1993-2004 regarding the frequency of ileocecal resections or right hemicolectomies in $C D{ }^{52}$. More recent data from Sweden on the other hand show a very different picture, with the 10-year cumulative incidence of an ileocecal resection having decreased from 40\% in patients diagnosed between 1990 and 1995 to $16 \%$ in patients diagnosed between 2004 and 2009. Furthermore, the need of a repeated ileocolic resection was as low as $5 \%$ after five years, but with no significant temporal changes in ileocolic resection rates seen over the whole time period 1990 to $2014^{53}$.

\section{Location}

Ileitis and terminal ileitis

A recent landmark randomized controlled study compared laparoscopic ileocecal resection with IFX therapy in non-stricturing terminal ileitis and found surgery to be equally good as IFX therapy in regards of quality of life, complications, repeat hospital admissions and complications to the given therapy ${ }^{54}$ but at a lower cost already after one year ${ }^{55}$.

During a median follow-up of four years $37 \%$ of patients in the IFX group went through a resection, while $26 \%$ patients in the resection group were put on aTNF later on. Altogether laparoscopic surgical resection in terminal ileitis may be an alternative to aTNF in inducing remission in unifocal disease. In most cases both therapies may be reasonable options as 
first line therapy, and it may therefore be down to the choice of the patient which therapy is used firsthand. Even though the risk of repeat ileocolic resection is low ${ }^{53}$ there is however a subsequent risk of needing either surgery or aTNF as secondary therapy at a later stage and patients should be informed of this as well.

Endoscopic recurrence is apparent in a majority of patients already within the first year after resectional surgery for ileal $C D^{56}$ and the severity of the endoscopic recurrence may in some way also give information on the risk of clinical and/or surgical recurrence ${ }^{5758}$. Some patients are more prone to have a recurrence of their ileocolic disease, e.g those who continue to smoke ${ }^{5960}$, have perforating disease ${ }^{6061}$, a short duration between $C D$ diagnosis and surgery as well as between primary and repeat surgery ${ }^{62-64}$, or have peri-anal disease ${ }^{62}$ 64. Moreover, some studies have found histopathological factors like presence of granulomas in the resection margin of the small bowel ${ }^{65}$ or mesentery ${ }^{66}$ as well as myenteric plexitis ${ }^{67} 68$ to be associated with a higher risk of post-operative recurrence.

An alternative to surgical resection of a strictured small bowel segment may be strictureplasty. The method was initially described by Emanoel Lee, Oxford, who transferred the technique from tuberculosis surgery to $C D$ surgery $^{69}$. In the beginning the technique was mainly used in patients with multiple short strictures in order to diminish the risk of developing intestinal failure in the long run. Later a number of more advanced methods have been developed with long ileal segments of skipped lesions and strictures, the Michelassi isoperistaltic side-to-side strictureplasty being the most well-known ${ }^{70}$. A recent addition to strictureplasties is the method described by de Buck van Overstraeten et $a l^{71}$. In patients with a wide-spread ileal disease, a long side-to-side isoperistaltic strictureplasty involving the ileocecal valve is used in order to save bowel length. 
In patients with short strictures of the terminal ileum balloon dilation may also be an option in order to defer surgery ${ }^{72}$. There is a risk of perforation at time of dilation and it has been suggested that it would be safer in an anastomosis compared with a de novo stricture but a meta-analysis could not verify this and both seems safe ${ }^{73}$. Like in resectional surgery, smokers have a less favorable outcome of an endoscopic dilation ${ }^{74}$ and this emphasises the importance of stopping smoking in $\mathrm{CD}^{75}$. There seems, however, to be an increased risk of surgical complications in patients failing a balloon dilatation of anastomotic strictures in comparison with those going straight to repeat resection, and the endoscopist as well as the patient should be aware of this ${ }^{76}$. In strictures of the colon the risk of colorectal cancer has to be considered ${ }^{77} 78$ and resection is recommended rather than strictureplasty or dilation ${ }^{79}$ 80.

Colitis

Crohn's disease of the colon can be widespread like ulcerative colitis but quite often more limited to only one or more segments. Historically, proctocolectomy or colectomy with an ileorectal anastomosis was the gold standard ${ }^{81}$, while today segmental resections have gained ground ${ }^{82-84}$ and indication for surgery is dependent on the extent and location of the disease. Before the 1990's approximately half of all patients with colonic CD would have had surgery within 10 years of their diagnosis and a quarter will have had an ileostomy ${ }^{85}$. More recent numbers from Sweden show a 5-year risk of colonic segmental resection in all CD patients to be around $8 \%$ while the risk of colectomy or proctectomy is $1 \%$ and $0.6 \%$ respectively ${ }^{50}$. There seems to be similar risks of repeat surgery regardless of whether subtotal colectomy or segmental resection is performed, but with better quality of life and bowel function in the latter case $\mathrm{s}^{8486}$. However, in the case of two or more involved 
segments there seems to be an increased risk for repeat surgery among patients with segmental resection ${ }^{87}$. A possibly important factor in the long-term chance of keeping the colon and avoiding a permanent stoma is the use of IM and aTNF as the increasing use of these drugs have coincided with a decrease in left colectomies and subtotal colectomies due to $C^{34} 52828889$.

In the acute setting of a severe $\mathrm{CD}$ colitis and/or severe perianal disease a diverting stoma may be a good option to colectomy and/or proctectomy ${ }^{90}$ 91. This may have advantages as it is a less invasive procedure in the very ill patient and also adds the possibility to let medications like IM and aTNF to anecdotally work better in a defunctioned bowel. It is however important to realize that only a third of the patients will have their stoma reversed and that in the long term only one of four reversed patients will keep their bowel continuity $^{91}$. Also, the outcome of a diverting stoma is somewhat worse in the era of aTNFs, both in the early response rate and long-term outcome ${ }^{91}$. This is possibly due to the selection of a group of more ill patients today as most of them will have failed both IM and aTNF therapy before being offered a diversion, while a diversion was offered a lot earlier previously and possibly to patients who today would have responded well to medical therapy ${ }^{91}$.

In the case of proctocolectomy, end ileostomy is the gold standard but in highly selected cases restorative surgery may be offered to CD patients as well. Panis et al have shown that it is not unreasonable to offer the well-informed CD patient an ileal pouch anal anastomosis $(\text { IPAA })^{92}$. Our unit have been more prone to offering these patients a Kock's continent ileostomy $(\mathrm{Cl})^{93}$ as complications are somewhat less difficult to deal with in the abdomen compared within the pelvis. Apart from a well-informed patient strict criterions should be 
used and only offering it to patient without signs of $C D$ in small bowel for a minimum of five years (verified with capsule endoscopy and/or small bowel MRI) and tolerance to IM and/or $\mathrm{aTNF}^{94}$ and in the case of IPAA also no history or signs of perianal disease ${ }^{92}$.

In some instances, a proctectomy, or pouchectomy, is still needed in the end and it is a wellknown fact that these patients may have a complicated perineal wound healing in up to $55 \%$ and around $50 \%$ have not healed within three months ${ }^{95-97}$. A recent study by Li et al has shown the importance of dealing with the perianal sepsis prior to the proctectomy letting the area to cool down, preferably with a stepwise approach with first a diverting stoma 96 and then possible also the use of aTNF ${ }^{98}$.

\section{Disease behavior}

There are epidemiologic studies suggesting that CD has evolved towards earlier detection and is associated with less complications ${ }^{27}$. Yet, contradictory to this, other studies show that the indication to surgery in $C D$ has shifted to more complicated procedures with fistulizing disease ${ }^{52}$. There is an inherent risk of trying medical therapy too long in the nonresponding patient and this has been shown to be associated not only with deterioration of the patient, with weight loss and development of perforating disease, but also with more surgical complications and need of a stoma (Figure 1$)^{99} 100$.

It has been shown that apart from smoking, anemia, weight-loss and hypo-albuminemia, also perforating disease and colonic $C D$ have an increased risk of anastomotic complications ${ }^{101-104}$. Moreover, the risk of anastomotic complications increases with the number of risk factors present at time of surgery, approaching $50 \%$ in the event of three or

four risk factors ${ }^{101} 102$. It is important to evaluate the patient prior to surgery and optimize 
with enteral nutrition (or parenteral if enteral nutrition is ineffective) and treat abdominal sepsis with drainage and antibiotics ${ }^{105-109}$. In the few cases were such optimization is not possible, it is safer to do a staged procedure with a split stoma, or possibly a diverting stoma, with closure a few months later when the patient has recovered ${ }^{110}$. Some patients will however be less prone to accept even a temporary stoma, and in this situation it is of outmost importance to evaluate the risks for the individual patient in case of an anastomotic dehiscence. Some patients may be well fit to tolerate a major complication and severe secondary morbidity (with repeat laparotomy, defunctioning stoma and possibly intensive care) and a calculated risk may be justified. Other patients will not have enough reserves, e.g. due to impaired general condition and/or old age, to manage such complication and there will be risk of mortality in case of a dehiscence ${ }^{111}$. All patients, but especially high-risk patients, deserve to be discussed in a multidisciplinary team conference (MDT) prior to surgery and thereafter have an informed consent on a surgical and perioperative plan ${ }^{112}$. The team however must always remember that calculated risks must be the decision of the patient, as he/she is the one who will suffer the possible consequences.

The MDT is important in the care of patients with IBD, and especially the severely ill patients with a more complicated disease ${ }^{112-114}$. There is a general consensus that the IBD MDT require presence of IBD oriented gastroenterologist/gastroenterologists and colorectal surgeon/surgeons, radiologist, IBD nurse and preferably also a pathologist 112113

In the preoperative setting patients should be evaluated not only to have the proper indications for surgery, including a proper radiological and endoscopic investigation, but also regarding risk factors and nutritional, medical and surgical optimization. The next step should be the surgical planning, making sure the right procedure is done at the right time 
and by the right team ${ }^{114}$. At time of surgery it is important to understand the importance of not only the experience of the surgical team but the whole IBD team of the unit ${ }^{115}$. In the uncomplicated setting laparoscopic surgery is gold standard but far more important is that the appropriate approach is used depending on the complexity of the disease and the experience of the surgeon ${ }^{79} 116$.

Unless there already has been a post-operative medical plan for the patient at time of surgery there should be a new discussion at the $\mathrm{MDT}^{115}$. As mentioned before, penetrating disease $^{6061}$, short duration between CD diagnosis and surgery ${ }^{62} 63$ and repeated surgery ${ }^{64}$ are associated with an increased risk of further disease recurrence, but the most important factor is smoking. In a meta-analysis a twofold increased risk of clinical recurrence and a 2.5fold increase in surgical recurrence was found among smokers ${ }^{59}$. Endoscopic recurrence is apparent in a majority of patients already within the first year after resectional surgery for $C D^{56}$ and in the case of ileal disease a general rule is ileocolonoscopic evaluation within 6-12 months in order to evaluate the need of and tailor post-operative therapy with IM and/or biologicals ${ }^{79}$. Less is known in regards of the best post-operative management but active endoscopic monitoring leads to better outcome $\mathrm{e}^{117}$ and the value of stop smoking must be made clear for the patient.

\section{Conclusion}

Crohn's disease is yet without a medical, as well as surgical cure which is why the therapeutic aim still is symptom control. There is an increasing incidence and prevalence and some evidence is suggesting more colonic location and inflammatory behavior than previously but at the same time there are signs of more complicated disease among patients in need of surgery. Medical and surgical therapies should be used as complementary 
methods and multidisciplinary discussions are essential in achieving minimal symptomatic load and highest possible quality of life. 


\section{References}

1. Podolsky DK. Inflammatory bowel disease. N Engl J Med 2002;347(6):417-29.

2. Vind I, Riis L, Jess $T$, et al. Increasing incidences of inflammatory bowel disease and decreasing surgery rates in Copenhagen City and County, 2003-2005: a population-based study from the Danish Crohn colitis database. Am J Gastroenterol 2006;101(6):1274-82.

3. Crohn BB, Ginzburg L, Oppenheimer GD. Regional ileitis: A pathologic and clinical entity. Jama 1932;1932(99):1323-29.

4. Pimentel $\mathrm{M}$, Chang $\mathrm{M}$, Chow EJ, et al. Identification of a prodromal period in Crohn's disease but not ulcerative colitis. Am J Gastroenterol 2000;95(12):3458-62.

5. Hellers $\mathrm{G}$, Bergstrand $\mathrm{O}$, Ewerth $\mathrm{S}$, et al. Occurrence and outcome after primary treatment of anal fistulae in Crohn's disease. Gut 1980;21(6):525-7.

6. Schwartz DA, Loftus EV, Jr., Tremaine WJ, et al. The natural history of fistulizing Crohn's disease in Olmsted County, Minnesota. Gastroenterology 2002;122(4):875-80.

7. Michelassi F, Stella M, Balestracci T, et al. Incidence, diagnosis, and treatment of enteric and colorectal fistulae in patients with Crohn's disease. Ann Surg 1993;218(5):660-6.

8. Lindgren A, Wallerstedt S, Olsson R. Prevalence of Crohn's disease and simultaneous occurrence of extraintestinal complications and cancer. An epidemiologic study in adults. Scand J Gastroenterol 1996;31(1):74-8.

9. Tang LY, Rawsthorne P, Bernstein CN. Are perineal and luminal fistulas associated in Crohn's disease? A population-based study. Clin Gastroenterol Hepatol 2006;4(9):1130-4.

10. Sands BE. From symptom to diagnosis: clinical distinctions among various forms of intestinal inflammation. Gastroenterology 2004;126(6):1518-32.

11. Satsangi J, Silverberg MS, Vermeire $S$, et al. The Montreal classification of inflammatory bowel disease: controversies, consensus, and implications. Gut 2006;55(6):749-53.

12. Bernklev T, Jahnsen J, Lygren I, et al. Health-related quality of life in patients with inflammatory bowel disease measured with the short form-36: psychometric assessments and a comparison with general population norms. Inflamm Bowel Dis 2005;11(10):909-18.

13. Canavan C, Abrams KR, Hawthorne B, et al. Long-term prognosis in Crohn's disease: factors that affect quality of life. Aliment Pharmacol Ther 2006;23(3):377-85.

14. Blondel-Kucharski F, Chircop C, Marquis P, et al. Health-related quality of life in Crohn's disease: a prospective longitudinal study in 231 patients. Am J Gastroenterol 2001;96(10):2915-20.

15. Casellas F, Vivancos JL, Sampedro M, et al. Relevance of the phenotypic characteristics of Crohn's disease in patient perception of health-related quality of life. Am J Gastroenterol 2005;100(12):2737-42.

16. Andersson $P$, Olaison $G$, Bendtsen $P$, et al. Health related quality of life in Crohn's proctocolitis does not differ from a general population when in remission. Colorectal Dis 2003;5(1):56-62.

17. Tillinger W, Mittermaier C, Lochs $\mathrm{H}$, et al. Health-related quality of life in patients with Crohn's disease: influence of surgical operation--a prospective trial. Dig Dis Sci 1999;44(5):932-8.

18. Larsson K, Lööf L, Rönnblom A, et al. Quality of life for patients with exacerbation in inflammatory bowel disease and how they cope with disease activity. J Psychosom Res 2008;64(2):139-48.

19. Casellas F, Rodrigo L, Nino $P$, et al. Sustained improvement of health-related quality of life in Crohn's disease patients treated with infliximab and azathioprine for 4 years. Inflamm Bowel Dis 2007;13(11):1395-400. doi: 10.1002/ibd.20205

20. Casellas F, Lopez-Vivancos J, Badia X, et al. Influence of inflammatory bowel disease on different dimensions of quality of life. Eur J Gastroenterol Hepatol 2001;13(5):567-72.

21. Silverstein MD, Loftus EV, Sandborn WJ, et al. Clinical course and costs of care for Crohn's disease: Markov model analysis of a population-based cohort. Gastroenterology 1999;117(1):49-57.

22. Andrews HA, Keighley MR, Alexander-Williams J, et al. Strategy for management of distal ileal Crohn's disease. Br J Surg 1991;78(6):679-82. 
23. Andersson $\mathrm{P}$, Olaison $\mathrm{G}$, Bodemar $\mathrm{G}$, et al. Low symptomatic load in Crohn's disease with surgery and medicine as complementary treatments. Scand J Gastroenterol 1998;33(4):423-29.

24. Casellas F, Lopez-Vivancos J, Badia X, et al. Impact of surgery for Crohn's disease on healthrelated quality of life. Am J Gastroenterol 2000;95(1):177-82.

25. Ponsioen CY, de Groof EJ, Eshuis EJ, et al. Laparoscopic ileocaecal resection versus infliximab for terminal ileitis in Crohn's disease: a randomised controlled, open-label, multicentre trial. Lancet Gastroenterol Hepatol 2017;2(11):785-92. doi: 10.1016/S2468-1253(17)30248-0

26. Ng SC, Shi HY, Hamidi N, et al. Worldwide incidence and prevalence of inflammatory bowel disease in the 21st century: a systematic review of population-based studies. Lancet 2018;390(10114):2769-78. doi: 10.1016/S0140-6736(17)32448-0 [published Online First: 2017/10/21]

27. Zhulina $\mathrm{Y}$, Udumyan $\mathrm{R}$, Henriksson I, et al. Temporal trends in non-stricturing and non-penetrating behaviour at diagnosis of Crohn's disease in Orebro, Sweden: a population-based retrospective study. J Crohns Colitis 2014;8(12):1653-60. doi: 10.1016/j.crohns.2014.07.006

S1873-9946(14)00219-0 [pii] [published Online First: 2014/08/13]

28. Lapidus A. Crohn's disease in Stockholm County during 1990-2001: an epidemiological update. World J Gastroenterol 2006;12(1):75-81.

29. Everhov AH, Halfvarson J, Myrelid P, et al. Incidence and Treatment of Patients Diagnosed With Inflammatory Bowel Diseases at 60 Years or Older in Sweden. Gastroenterology 2018;154(3):518-28.e15. doi: 10.1053/j.gastro.2017.10.034 [published Online First: 2017/11/06]

30. Torres J, Mehandru S, Colombel JF, et al. Crohn's disease. Lancet 2017;389(10080):1741-55. doi: 10.1016/S0140-6736(16)31711-1 [published Online First: 2016/12/05]

31. Lichtenstein GR, Hanauer SB, Sandborn WJ. Management of Crohn's disease in adults. Am J Gastroenterol 2009;104(2):465-83.

32. Colombel JF, Sandborn WJ, Reinisch W, et al. Infliximab, azathioprine, or combination therapy for Crohn's disease. N Engl J Med 2010;362(15):1383-95. doi: 10.1056/NEJMoa0904492 [published Online First: 2010/04/16]

33. Larsen L, Drewes AM, Broberg MCH, et al. Changing Infliximab Prescription Patterns in Inflammatory Bowel Disease: A Population-Based Cohort Study, 1999-2014. Inflamm Bowel Dis 2018;24(2):433-39. doi: 10.1093/ibd/izx038 [published Online First: 2018/01/24]

34. Olivera P, Spinelli A, Gower-Rousseau C, et al. Surgical rates in the era of biological therapy: up, down or unchanged? Curr Opin Gastroenterol 2017 doi: 10.1097/MOG.0000000000000361

35. Eberhardson M, Soderling JK, Neovius M, et al. Anti-TNF treatment in Crohn's disease and risk of bowel resection-a population based cohort study. Aliment Pharmacol Ther 2017;46(6):58998. doi: 10.1111/apt.14224 [published Online First: 2017/07/29]

36. van der Valk ME, Mangen MJ, Leenders M, et al. Healthcare costs of inflammatory bowel disease have shifted from hospitalisation and surgery towards anti-TNFalpha therapy: results from the COIN study. Gut 2014;63(1):72-9. doi: 10.1136/gutjnl-2012-303376

37. Keller J, Panter H, Layer P. Management of the short bowel syndrome after extensive small bowel resection. Best Pract Res Clin Gastroenterol 2004;18(5):977-92.

38. Agwunobi AO, Carlson GL, Anderson ID, et al. Mechanisms of intestinal failure in Crohn's disease. Dis Colon Rectum 2001;44(12):1834-7.

39. Thompson JS, Iyer KR, DiBaise JK, et al. Short bowel syndrome and Crohn's disease. J Gastrointest Surg 2003;7(8):1069-72.

40. Fazio VW, Marchetti F, Church M, et al. Effect of resection margins on the recurrence of Crohn's disease in the small bowel. A randomized controlled trial. Ann Surg 1996;224(4):563-71.

41. Post S, Herfarth $C$, Bohm E, et al. The impact of disease pattern, surgical management, and individual surgeons on the risk for relaparotomy for recurrent Crohn's disease. Ann Surg 1996;223(3):253-60. 
42. Raab Y, Bergström R, Ejerblad S, et al. Factors influencing recurrence in Crohn's disease. An analysis of a consecutive series of 353 patients treated with primary surgery. Dis Colon Rectum 1996;39(8):918-25.

43. Poggioli G, Pierangeli F, Laureti S, et al. Review article: indication and type of surgery in Crohn's disease. Aliment Pharmacol Ther 2002;16 Suppl 4:59-64.

44. Yamamoto T, Bain IM, Allan RN, et al. An audit of strictureplasty for small-bowel Crohn's disease. Dis Colon Rectum 1999;42(6):797-803.

45. Yamamoto T, Allan RN, Keighley MR. Long-term outcome of surgical management for diffuse jejunoileal Crohn's disease. Surgery 2001;129(1):96-102.

46. Yamamoto T, Fazio VW, Tekkis PP. Safety and efficacy of strictureplasty for Crohn's disease: a systematic review and meta-analysis. Dis Colon Rectum 2007;50(11):1968-86.

47. Peyrin-Biroulet L, Harmsen WS, Tremaine WJ, et al. Surgery in a population-based cohort of Crohn's disease from Olmsted County, Minnesota (1970-2004). Am J Gastroenterol 2012;107(11):1693-701. doi: 10.1038/ajg.2012.298

ajg2012298 [pii] [published Online First: 2012/09/05]

48. Peyrin-Biroulet L, Loftus EV, Jr., Colombel JF, et al. The natural history of adult Crohn's disease in population-based cohorts. Am J Gastroenterol 2010;105(2):289-97. doi:

10.1038/ajg.2009.579 [published Online First: 2009/10/29]

49. Frolkis AD, Dykeman J, Negron ME, et al. Risk of surgery for inflammatory bowel diseases has decreased over time: a systematic review and meta-analysis of population-based studies. Gastroenterology 2013;145(5):996-1006. doi: 10.1053/j.gastro.2013.07.041

50. Kalman D, Nordenvall C, Hallqvist Everhov A, et al. OP016 Need for primary abdominal surgery, but not repeated surgery, has decreased: a nationwide study of temporal trends in Crohn surgery in Sweden 1990-2014. Journal of Crohn's and Colitis 2018;12(supplement_1):S011S12. doi: 10.1093/ecco-jcc/jjx180.015

51. Jeuring SF, van den Heuvel TR, Liu LY, et al. Improvements in the Long-Term Outcome of Crohn's Disease Over the Past Two Decades and the Relation to Changes in Medical Management: Results from the Population-Based IBDSL Cohort. Am J Gastroenterol 2017;112(2):325-36. doi: 10.1038/ajg.2016.524 [published Online First: 2016/12/07]

52. Jones DW, Finlayson SR. Trends in surgery for Crohn's disease in the era of infliximab. Ann Surg 2010;252(2):307-12. doi: 10.1097/SLA.0b013e3181e61df5 [published Online First: 2010/06/30]

53. Kalman D, Nordenvall C, Hallqvist Everhov A, et al. DOP042 Need for ileocaecal resections, but not ileo-colic re-resections, has decreased: a nationwide study of temporal trends in Crohn surgery in Sweden 1990-2014. Journal of Crohn's and Colitis 2018;12(supplement_1):S060S61. doi: 10.1093/ecco-jcc/jjx180.079

54. Ponsioen CY, de Groof EJ, Eshuis EJ, et al. Laparoscopic ileocaecal resection versus infliximab for terminal ileitis in Crohn's disease: a randomised controlled, open-label, multicentre trial. Lancet Gastroenterol Hepatol 2017 doi: 10.1016/S2468-1253(17)30248-0

55. de Groof J, Bemelman W, Eshuis E, et al. OP015 Cost-effectiveness of laparoscopic ileocecal resection versus infliximab treatment of terminal ileitis in Crohn's disease: the LIR!C TRIAL. Journal of Crohn's and Colitis 2017;11(suppl_1):S9-S10. doi: 10.1093/ecco-jcc/jjx002.014

56. Renna S, Camma C, Modesto I, et al. Meta-analysis of the placebo rates of clinical relapse and severe endoscopic recurrence in postoperative Crohn's disease. Gastroenterology 2008;135(5):1500-9. doi: 10.1053/j.gastro.2008.07.066

57. Rutgeerts $P$, Geboes K, Vantrappen $G$, et al. Predictability of the postoperative course of Crohn's disease. Gastroenterology 1990;99(4):956-63.

58. Olaison G, Smedh K, Sjodahl R. Natural course of Crohn's disease after ileocolic resection: endoscopically visualised ileal ulcers preceding symptoms. Gut 1992;33(3):331-35. doi: 10.1136/gut.33.3.331 
59. Reese GE, Nanidis T, Borysiewicz C, et al. The effect of smoking after surgery for Crohn's disease: a meta-analysis of observational studies. Int J Colorectal Dis 2008;23(12):1213-21.

60. Li Y, Zhu W, Zuo L, et al. Frequency and risk factors of postoperative recurrence of Crohn's disease after intestinal resection in the Chinese population. J Gastrointest Surg 2012;16(8):1539-47. doi: 10.1007/s11605-012-1902-x

61. Simillis C, Yamamoto T, Reese GE, et al. A meta-analysis comparing incidence of recurrence and indication for reoperation after surgery for perforating versus nonperforating Crohn's disease. Am J Gastroenterol 2008;103(1):196-205. doi: 10.1111/j.1572-0241.2007.01548.x

62. Yamamoto T, Watanabe T. Strategies for the prevention of postoperative recurrence of Crohn's disease. Colorectal Dis 2013;15(12):1471-80. doi: 10.1111/codi.12326

63. Papay $P$, Reinisch $W, H o E$, et al. The impact of thiopurines on the risk of surgical recurrence in patients with Crohn's disease after first intestinal surgery. Am J Gastroenterol 2010;105(5):1158-64. doi: 10.1038/ajg.2009.673

64. Gionchetti P, Dignass A, Danese S, et al. 3rd European Evidence-based Consensus on the Diagnosis and Management of Crohn's Disease 2016: Part 2: Surgical Management and Special Situations. J Crohns Colitis 2017;11(2):135-49. doi: 10.1093/ecco-jcc/jjw169

65. Simillis C, Jacovides M, Reese GE, et al. Meta-analysis of the role of granulomas in the recurrence of Crohn disease. Dis Colon Rectum 2010;53(2):177-85. doi: 10.1007/DCR.0b013e3181b7bfb0

00003453-201002000-00011 [pii] [published Online First: 2010/01/21]

66. Unger LW, Argeny S, Stift A, et al. Mesenteric granulomas independently predict long-term risk of surgical recurrence in Crohn's disease. Colorectal Disease 2019 doi: 10.1111/codi.14814 [published Online First: 2019, Aug 8]

67. Ferrante $M$, de Hertogh $G$, Hlavaty $T$, et al. The value of myenteric plexitis to predict early postoperative Crohn's disease recurrence. Gastroenterology 2006;130(6):1595-606. doi: S0016-5085(06)00336-2 [pii]

10.1053/j.gastro.2006.02.025 [published Online First: 2006/05/16]

68. Sokol H, Polin V, Lavergne-Slove A, et al. Plexitis as a predictive factor of early postoperative clinical recurrence in Crohn's disease. Gut 2009;58(9):1218-25. doi: 10.1136/gut.2009.177782

gut.2009.177782 [pii] [published Online First: 2009/07/25]

69. Lee EC, Papaioannou N. Minimal surgery for chronic obstruction in patients with extensive or universal Crohn's disease. Ann R Coll Surg Engl 1982(64):229-33.

70. Michelassi F, Hurst RD, Melis M, et al. Side-to-side isoperistaltic strictureplasty in extensive Crohn's disease: a prospective longitudinal study. Ann Surg 2000;232(3):401-8.

71. de Buck van Overstraeten A, Wolthuis AM, D'Hoore A. Modified side-to-side isoperistaltic strictureplasty over the ileocaecal valve for the surgical treatment of terminal ileal Crohn's disease: the ultimate bowel sparing technique? Colorectal Dis 2016;18(8):0311-3. doi: 10.1111/codi.13420

72. Van Assche G, Vermeire S, Rutgeerts P. Endoscopic therapy of strictures in Crohn's disease. Inflamm Bowel Dis 2007;13(3):356-58.

73. Bettenworth D, Gustavsson A, Atreja A, et al. A Pooled Analysis of Efficacy, Safety, and Long-term Outcome of Endoscopic Balloon Dilation Therapy for Patients with Stricturing Crohn's Disease. Inflamm Bowel Dis 2017;23(1):133-42. doi: 10.1097/MIB.0000000000000988 [published Online First: 2016/12/22]

74. Gustavsson A, Magnuson A, Blomberg B, et al. Smoking is a risk factor for recurrence of intestinal stricture after endoscopic dilation in Crohn's disease. Aliment Pharmacol Ther 2013;37(4):430-7. doi: 10.1111/apt.12176 [published Online First: 2012/12/05]

75. Cosnes J, Beaugerie L, Carbonnel F, et al. Smoking cessation and the course of Crohn's disease: an intervention study. Gastroenterology 2001;120(5):1093-99. 
76. Li Y, Stocchi L, Shen B, et al. Salvage surgery after failure of endoscopic balloon dilatation versus surgery first for ileocolonic anastomotic stricture due to recurrent Crohn's disease. Br J Surg 2015;102(11):1418-25; discussion 25. doi: 10.1002/bjs.9906

77. Maser EA, Sachar DB, Kruse D, et al. High rates of metachronous colon cancer or dysplasia after segmental resection or subtotal colectomy in Crohn's colitis. Inflamm Bowel Dis

2013;19(9):1827-32. doi: 10.1097/MIB.0b013e318289c166 [published Online First: 2013/05/15]

78. Kiran RP, Khoury W, Church JM, et al. Colorectal cancer complicating inflammatory bowel disease: similarities and differences between Crohn's and ulcerative colitis based on three decades of experience. Ann Surg 2010;252(2):330-5. doi: 10.1097/SLA.0b013e3181e61e69 [published Online First: 2010/07/14]

79. Bemelman WA, Warusavitarne J, Sampietro GM, et al. ECCO-ESCP Consensus on Surgery for Crohn's Disease. J Crohns Colitis 2018;12(1):1-16. doi: 10.1093/ecco-jcc/jjx061 [published Online First: 2017/05/13]

80. Kiran RP, Nisar PJ, Goldblum JR, et al. Dysplasia associated with Crohn's colitis: segmental colectomy or more extended resection? Ann Surg 2012;256(2):221-6. doi: 10.1097/SLA.0b013e31825f0709 [published Online First: 2012/07/14]

81. Fazio VW, Wu JS. Surgical therapy for Crohn's disease of the colon and rectum. Surg Clin North Am 1997;77(1):197-210.

82. Andersson P, Olaison G, Bodemar G, et al. Surgery for Crohn colitis over a twenty-eight-year period: fewer stomas and the replacement of total colectomy by segmental resection. Scand J Gastroenterol 2002;37(1):68-73.

83. Andersson $P$, Olaison $G$, Hallböök $O$, et al. Segmental resection or subtotal colectomy in Crohn's colitis? Dis Colon Rectum 2002;45(1):47-53.

84. Kiran RP, Nisar PJ, Church JM, et al. The role of primary surgical procedure in maintaining intestinal continuity for patients with Crohn's colitis. Ann Surg 2011;253(6):1130-5. doi: 10.1097/SLA.0b013e318212b1a4 [published Online First: 2011/03/12]

85. Lapidus A, Bernell O, Hellers G, et al. Clinical course of colorectal Crohn's disease: a 35-year follow-up study of 507 patients. Gastroenterology 1998;114(6):1151-60.

86. Polle SW, Slors JF, Weverling GJ, et al. Recurrence after segmental resection for colonic Crohn's disease. Br J Surg 2005;92(9):1143-9. doi: 10.1002/bjs.5050 [published Online First: 2005/07/22]

87. Tekkis PP, Purkayastha S, Lanitis $S$, et al. A comparison of segmental vs subtotal/total colectomy for colonic Crohn's disease: a meta-analysis. Colorectal Dis 2006;8(2):82-90.

88. Ramadas AV, Gunesh S, Thomas GA, et al. Natural history of Crohn's disease in a populationbased cohort from Cardiff (1986-2003): a study of changes in medical treatment and surgical resection rates. Gut 2010;59(9):1200-6. doi: 10.1136/gut.2009.202101

gut.2009.202101 [pii] [published Online First: 2010/07/24]

89. Aaltonen G, Carpelan-Holmstrom M, Keranen I, et al. Risk factors for proctectomy in consecutive Crohn's colitis surgical patients in a reference colorectal centre. Int J Colorectal Dis 2019;34(8):1401-06. doi: 10.1007/s00384-019-03337-8 [published Online First: 2019/06/30]

90. Edwards CM, George BD, Jewell DP, et al. Role of a defunctioning stoma in the management of large bowel Crohn's disease. Br J Surg 2000;87(8):1063-6.

91. Marti-Gallostra M, Myrelid P, Mortensen N, et al. The role of a defunctioning stoma for colonic and perianal Crohn's disease in the biological era. Scand J Gastroenterol 2017;52(3):251-56. doi: 10.1080/00365521.2016.1205127

92. Panis Y, Poupard B, Nemeth J, et al. Ileal pouch/anal anastomosis for Crohn's disease. Lancet 1996;347(9005):854-7. [published Online First: 1996/03/30]

93. Kock NG. Intra-abdominal "reservoir" in patients with permanent ileostomy. Preliminary observations on a procedure resulting in fecal "continence" in five ileostomy patients. Arch Surg 1969;99(2):223-31. [published Online First: 1969/08/01] 
94. Myrelid P, Block M, editors. The Kock Pouch: Springer, 2019.

95. Anthony JP, Mathes SJ. The recalcitrant perineal wound after rectal extirpation. Applications of muscle flap closure. Arch Surg 1990;125(10):1371-6; discussion 76-7. doi: 10.1001/archsurg.1990.01410220155022 [published Online First: 1990/10/01]

96. Li W, Stocchi L, Elagili F, et al. Healing of the perineal wound after proctectomy in Crohn's disease patients: only preoperative perineal sepsis predicts poor outcome. Tech Coloproctol 2017;21(9):715-20. doi: 10.1007/s10151-017-1695-8 [published Online First: 2017/10/13]

97. Baudot $P$, Keighley MR, Alexander-Williams J. Perineal wound healing after proctectomy for carcinoma and inflammatory disease. Br J Surg 1980;67(4):275-6.

98. van Dullemen HM, de Jong E, Slors F, et al. Treatment of therapy-resistant perineal metastatic Crohn's disease after proctectomy using anti-tumor necrosis factor chimeric monoclonal antibody, cA2: report of two cases. Dis Colon Rectum 1998;41(1):98-102.

99. lesalnieks I, Kilger A, Glass H, et al. Intraabdominal septic complications following bowel resection for Crohn's disease: detrimental influence on long-term outcome. Int J Colorectal Dis 2008;23(12):1167-74.

100. lesalnieks I, Kilger A, Glass H, et al. Perforating Crohn's ileitis: delay of surgery is associated with inferior postoperative outcome. Inflamm Bowel Dis 2010;16(12):2125-30. doi: 10.1002/ibd.21303 [published Online First: 2010/09/18]

101. Myrelid P, Olaison G, Sjödahl R, et al. Thiopurine therapy is associated with postoperative intraabdominal septic complications in abdominal surgery for Crohn's disease. Dis Colon Rectum 2009;52(8):1387-94. doi: 10.1007/DCR.0b013e3181a7ba96

00003453-200908000-00005 [pii] [published Online First: 2009/07/21]

102. Yamamoto T, Allan RN, Keighley MR. Risk factors for intra-abdominal sepsis after surgery in Crohn's disease. Dis Colon Rectum 2000;43(8):1141-5.

103. Post $S$, Betzler M, von Ditfurth $B$, et al. Risks of intestinal anastomoses in Crohn's disease. Ann Surg 1991;213(1):37-42.

104. Sharma A, Deeb AP, lannuzzi JC, et al. Tobacco smoking and postoperative outcomes after colorectal surgery. Ann Surg 2013;258(2):296-300. doi: 10.1097/SLA.0b013e3182708cc5

105. Smedh $\mathrm{K}$, Andersson $\mathrm{M}$, Johansson $\mathrm{H}$, et al. Preoperative management is more important than choice of sutured or stapled anastomosis in Crohn's disease. Eur J Surg 2002;168(3):154-7.

106. Rocha A, Bessa I, Lago P, et al. Preoperative Enteral Nutrition and Surgical Outcomes in Adults with Crohn's Disease: A Systematic Review. GE Port J Gastroenterol 2019;26(3):184-95. doi: 10.1159/000494674 [published Online First: 2019/06/14]

107. Ge X, Tang S, Yang X, et al. The role of exclusive enteral nutrition in the preoperative optimization of laparoscopic surgery for patients with Crohn's disease: A cohort study. Int J Surg 2019;65:39-44. doi: 10.1016/j.ijsu.2019.03.012 [published Online First: 2019/03/25]

108. Li G, Ren J, Wang G, et al. Preoperative exclusive enteral nutrition reduces the postoperative septic complications of fistulizing Crohn's disease. Eur J Clin Nutr 2014;68(4):441-6. doi: 10.1038/ejcn.2014.16 [published Online First: 2014/02/20]

109. Grass F, Pache B, Martin D, et al. Preoperative Nutritional Conditioning of Crohn's PatientsSystematic Review of Current Evidence and Practice. Nutrients 2017;9(6) doi: 10.3390/nu9060562 [published Online First: 2017/06/08]

110. Myrelid P, Söderholm JD, Olaison G, et al. Split stoma in resectional surgery of high risk patients with ileocolonic Crohn's disease. Colorectal Dis 2012;14(2):188-93. doi: 10.1111/j.14631318.2011.02578.x [published Online First: 2011/06/22]

111. Sacleux S-C, Sarter H, Fumery M, et al. Post-operative complications in elderly onset inflammatory bowel disease: a population-based study. Aliment Parmacol Ther 2018 doi: 10.1111/apt.14790

112. Morar PS, Sevdalis N, Warusavitarne J, et al. Establishing the aims, format and function for multidisciplinary team-driven care within an inflammatory bowel disease service: a 
multicentre qualitative specialist-based consensus study. Frontline Gastroenterol 2018;9(1):29-36. doi: 10.1136/flgastro-2017-100835 [published Online First: 2018/02/28]

113. Morar P, Read J, Arora S, et al. Defining the optimal design of the inflammatory bowel disease multidisciplinary team: results from a multicentre qualitative expert-based study. Frontline Gastroenterol 2015;6(4):290-97. doi: 10.1136/flgastro-2014-100549 [published Online First: 2015/10/01]

114. Morar PS, Hollingshead J, Bemelman W, et al. Establishing Key Performance Indicators [KPIs] and Their Importance for the Surgical Management of Inflammatory Bowel Disease-Results From a Pan-European, Delphi Consensus Study. J Crohns Colitis 2017;11(11):1362-68. doi: 10.1093/ecco-jcc/jjx099 [published Online First: 2017/09/30]

115. Brown SR, Fearnhead NS, Faiz OD, et al. The Association of Coloproctology of Great Britain and Ireland consensus guidelines in surgery for inflammatory bowel disease. Colorectal Dis 2018;20 Suppl 8:3-117. doi: 10.1111/codi.14448 [published Online First: 2018/12/07]

116. Strong S, Steele SR, Boutrous M, et al. Clinical Practice Guideline for the Surgical Management of Crohn's Disease. Dis Colon Rectum 2015;58(11):1021-36. doi: 10.1097/DCR.0000000000000450 [published Online First: 2015/10/09]

117. De Cruz $P$, Kamm MA, Hamilton AL, et al. Crohn's disease management after intestinal resection: a randomised trial. Lancet 2015;385(9976):1406-17. doi: 10.1016/S0140-6736(14)61908-5

118. Levine A, Griffiths A, Markowitz J, et al. Pediatric modification of the Montreal classification for inflammatory bowel disease: the Paris classification. Inflamm Bowel Dis 2011;17(6):1314-21. doi: 10.1002/ibd.21493 


\section{Tables and figures}

\section{Table 1}

Montreal classification of Crohn's disease ${ }^{11}$. The "worst" type of the classification ever taking part in a patients life will the one used in the classification, i.e. a patient diagnosed at age 12 with inflammatory ileocacal disease will at first get the classification A1 L1 B1. When the same patient later in life develops colonic disease as well and developes an ileosigmoidal fistula and also a perianal fistula the new classification will be A1 L3 B3p.

\begin{tabular}{|l|l|l|l|l|}
\hline \multicolumn{2}{|l|}{ Montreal classification of Crohn's Disease } & $\begin{array}{l}\text { Disease } \\
\text { modifier }\end{array}$ \\
\hline $\begin{array}{l}\text { Age at diagnosis } \\
\text { (A) }\end{array}$ & $\begin{array}{l}\text { A1 } \\
\leq 16 \text { years of age } \\
\text { at diagnosis }\end{array}$ & $\begin{array}{l}\text { A2 } \\
17-40 \text { years of } \\
\text { age at diagnosis }\end{array}$ & $\begin{array}{l}\text { A3 } \\
>40 \text { years of age } \\
\text { at diagnosis }\end{array}$ & N/A \\
\hline $\begin{array}{l}\text { Location of the } \\
\text { disease (L) }\end{array}$ & $\begin{array}{l}\text { L1 } \\
\text { Ileal or ileocecal } \\
\text { disease }\end{array}$ & $\begin{array}{l}\text { L2 } \\
\text { Colonic disease }\end{array}$ & $\begin{array}{l}\text { L3 } \\
\text { Ileocolonic } \\
\text { disease (other } \\
\text { than ileocecal) }\end{array}$ & $\begin{array}{l}\text { I4 } \\
\text { Isolated upper } \\
\text { disease }\end{array}$ \\
\hline $\begin{array}{l}\text { Behavior of the } \\
\text { disease (B) }\end{array}$ & $\begin{array}{l}\text { B1 } \\
\text { Inflammatory, } \\
\text { non-stricturing, } \\
\text { non-penetrating } \\
\text { disease }\end{array}$ & $\begin{array}{l}\text { B2 } \\
\text { Stricturing } \\
\text { disease }\end{array}$ & $\begin{array}{l}\text { Penetrating } \\
\text { disease }\end{array}$ & $\begin{array}{l}\text { Perianal } \\
\text { disease }\end{array}$ \\
\hline
\end{tabular}

In pediatric Crohn's disease the modified Paris classification is used dividing e.g. small bowel disease to $L 1$ if the last $1 / 3$ of the ileum is affected and $L 4 b$ if the small bowel is affected in the proximal 2/3 of ileum up to the ligament of Treitz. Upper gastrointestinal Crohn's disease proximal of the ligament of Treitz is classified as $L 4 a^{118}$. 


\section{Figure 1}

The vicious route of severe Crohn's disease refractory to medical therapy. With increasing non-responsive attempts with medical therapies (e.g. steroids, immunomodulators and/or biologicals) patients may develop clinical impairment with increasing number of surgical risk factors (e.g. weight loss, hypo-albuminemia, perforating disease). Before deciding on a primary anastomosis the risk of an anastomotic dehiscence should be evaluated as well as if the patient is fit enough to survive such complication or not. The patient must be fully aware of such risks as there is risk of severe post-operative morbidity and mortality.

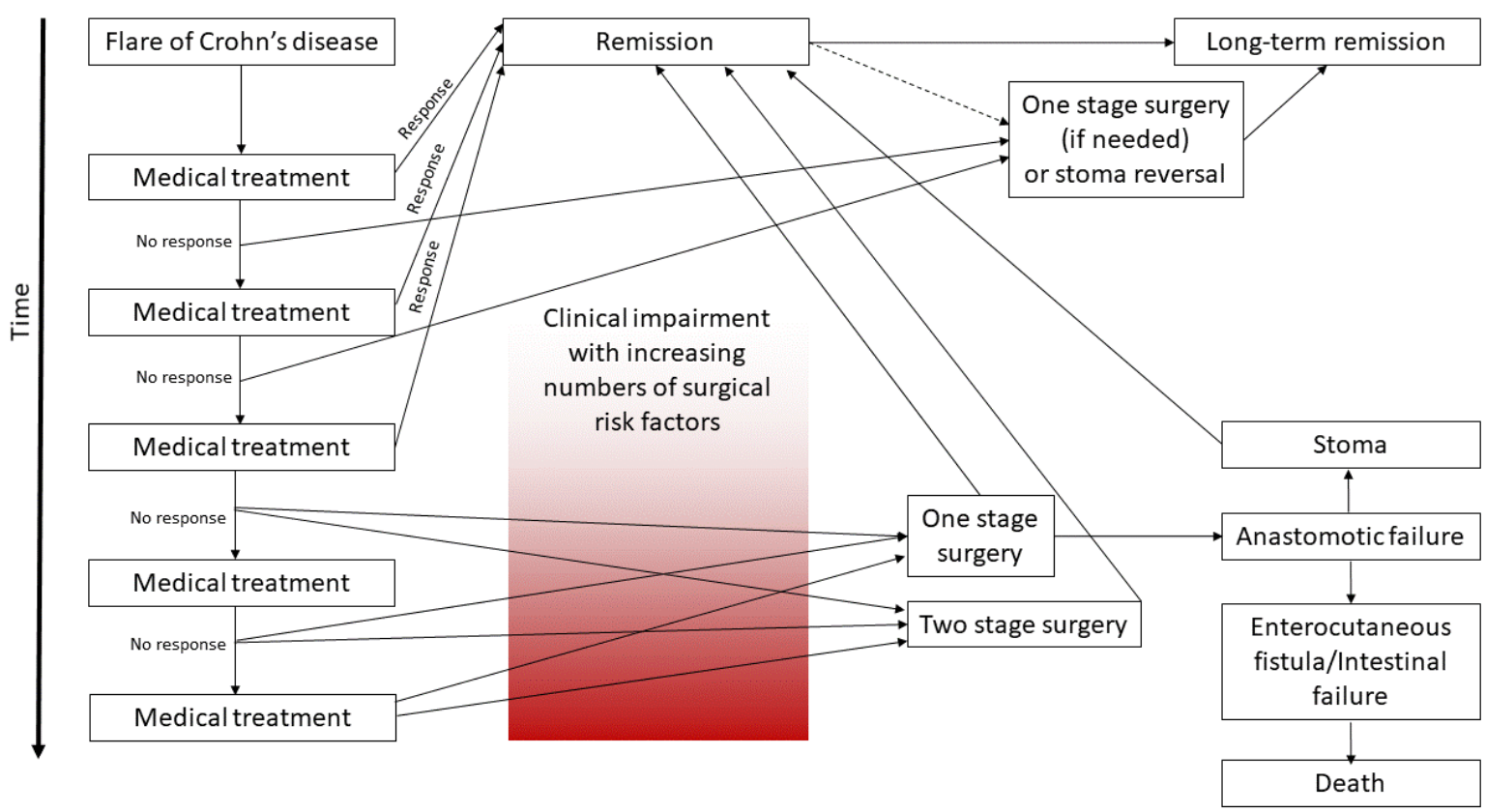

